\title{
Maxie C. Maultsby Jr.
}

1932-2016

\begin{abstract}
W niedzielę 28 sierpnia $2016 \mathrm{r}$. $\mathrm{w}$ otoczeniu najbliższej rodziny - żony i córki - zmarl profesor Maxie C. Maultsby Jr., światowej sławy psychiatra, jeden z pionierów terapii poznawczo-behawioralnych, twórca popularnej w Polsce Racjonalnej Terapii Zachowania (RTZ), często stosowanej przez psychoonkologów. Profesor Maultsby jest autorem lub współautorem kilkudziesięciu publikacji naukowych, 12 książek tłumaczonych na wiele języków, kilkunastu rozdziałów książkowych oraz niezliczonej
\end{abstract} ilości artykułów popularno-

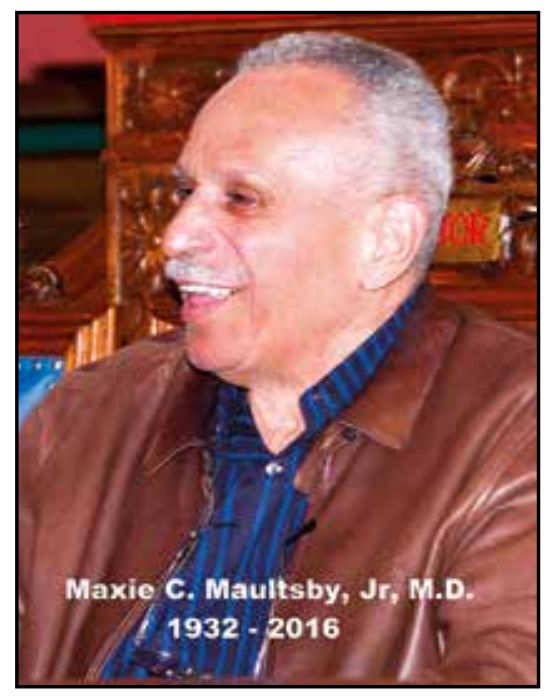

z psychiatrii ogólnej, a następnie psychiatrii dzieci i młodzieży na University of Wisconsin, gdzie został nauczycielem akademickim. Okres od ukończenia medycyny do 1970 r. to czas intensywnych studiów i inspiracji pracami m.in. Watsona i Rayner, Hebba, Łurii, Pawłowa, Skinnera, Rottera, Razrana, Lazarusa oraz Grace'a i Grahama. Dodatkowo podczas rezydentury dokształcał się w obszarze najnowocześniejszych wtedy metod psychoterapeutycznych u Josepha Wolpe, Wolfganga Luthe'a (trening autogenny i redukcja stresu) i Albernaukowych. Otrzymał wiele nagród i wyróżnień za zasługi dla psychiatrii i psychoterapii, $w$ tym najwyższe: Amerykańskiego Towarzystwa Psychiatrycznego oraz Narodowego Towarzystwa Terapeutów Poznawczo-Behawioralnych za całokształt dokonań i dorobek życia zawodowego. Jego głównym zainteresowaniem było uczenie ludzi uwalniania samych siebie $\mathrm{z}$ cierpienia duchowego i emocjonalnego. Maultsby uważał, że u ludzi mających chemicznie i strukturalnie zdrowe mózgi większość cierpienia wypływa z wyuczonych nawyków emocjonalnych i utrzymywanych niezdrowych postaw, przekonań i myśli, więc interwencje psychoterapeutyczne mogą działać jedynie poprzez zmianę tych procesów poznawczych - RTZ odnosi się bezpośrednio właśnie do zmiany wspomnianych procesów.

Maxie Maultsby urodził się 24 kwietnia 1932 r. w Pensacola na Florydzie. Po ukończeniu Talladega College w Alabamie dostał stypendium na studia medyczne $w$ prestiżowym Case Western Reserve University w Cleveland, Ohio, gdzie w 1957 r. otrzymał stopień doktora medycyny. Po ukończeniu stażu lekarskiego otworzył praktykę ogólną w Cocoa na Florydzie, a następnie w 1962 r. kontynuowal pracę jako lekarz wojskowy Sił Powietrznych USA stacjonujących w Japonii i na Filipinach, otaczając opieką medyczną także rodziny lotników. Podczas swej pracy zauważył, że większość zgłaszających się do niego pacjentów miała somatyczne dolegliwości związane z nierozwiązanymi problemami emocjonalnymi czy psychicznymi. Dlatego też po czterech latach służby ukończył rezydenturę ta Ellisa - z tym ostatnim nawiązał bliską i trwałą wspótpracę.

Podczas pracy z Ellisem i jego Terapią Racjonalno-Emotywną (Rational Emotive Therapy) Maultsby stworzył w 1971 r. własną Racjonalną Terapię Zachowania (Rational Behavior Therapy) [1]. Później, pod wpływem Maultsby'ego, Ellis uzupełnił swoją terapię o interwencje behawioralne (szczególnie pracę z wyobraźnią) i przemianował RET na REBT (Rational Emotive Behavior Therapy - Racjonalno-Emotywną Terapię Behawioralną) [2].

W 1971 r. Maultsby został adiunktem, a w 1979 r. profesorem na University of Kentucky w Lexington. W 1973 r. założył tam Training and Treatment Center for Rational Behavior Therapy, którego był dyrektorem do 1987 r. i gdzie powstała większość jego prac. Następnie kierował ośrodkami psychiatrycznymi w Columbia (Karolina Południowa) i Las Vegas (Nevada), by przejąć ster Wydziału Psychiatrii na Uniwersytecie Howarda w Waszyngtonie - pracował tam aż do przejścia na emeryturę w 2004 r. i pozostał na fakultecie jako profesor emeritus aż do śmierci. W 2011 r. został profesorem $\mathrm{w}$ programie szkolenia rezydentów psychiatrii szpitala św. Elżbiety Wydziału Zdrowia Psychicznego w Waszyngtonie.

W połowie lat 80. ubiegłego wieku prof. Maultsby nawiązał współpracę z doktorem O. Carlem Simontonem, jednym ze sławnych pionierów psychoonkologii, co zaowocowało powiązaniem terapii poznawczo-behawioralnej z interwencjami psychoonkologicznymi. Simontona ujęło głęboko humanistyczne podejście Maultsby'ego i jego 
wrażliwość na drugiego człowieka oraz możliwość zastosowania RTZ $\mathrm{w}$ odniesieniu do cierpienia związanego z przekonaniami duchowymi i religijnymi. Simonton często podkreślał, że wprowadzenie RTZ do jego podejścia „było najistotniejszą zmianą w jego podejściu od 1971 r.", czyli od początku istnienia jego programu. Tak się też złożyło, że gdy w 1971 r. Maultsby wprowadzał stosowanie pracy z wyobraźnią jako sposobu zmiany nawyków emocjonalnych [3]. Simonton $-\mathrm{w}$ tym samym roku - wprowadził wyobraźnię do onkologii jako interwencję wspierającą nadzieję i pomagającą onkologicznie chorym zmienić swoje przekonania o chorobie i postawy wobec leczenia onkologicznego [4]. W ten sposób techniki RTZ stały się stałym elementem terapii simontonowskiej $[5,6]$ i okazały się skuteczne nie tylko w leczeniu objawów emocjonalnych, lecz także somatycznych, jak ból fizyczny u chorych onkologicznie [7, 8].

To właśnie w 1990 r. Carl Simonton przedstawił mojej żonie Aleksandrze i mnie podstawy RTZ i zachęcił do dalszego kształcenia $\mathrm{w}$ tym kierunku. W kwietniu 1992 r. Maultsby przyjechał po raz pierwszy do Polski - na zaproszenie profesora Janusza Rybakowskiego - i wygłosił wykłady na Wydziale Psychiatrii Akademii Medycznej w Bydgoszczy. Przeprowadził także trzydniowe warsztaty w RTZ w Ośrodku Gestalt Polskiego Stowarzyszenia Psychologów Praktyków w Krakowie. Na jego drugi przyjazd, w listopadzie 1992 r., zostały już przetłumaczone i wydane przez WDW Wulkan w Żninie jego książki: $A B C$ twoich emocji i Racjonalna Terapia Zachowania: podręcznik terapii poznawczo-behawioralnej. Podczas tej drugiej podróży wykłady i warsztaty w Poznaniu i Krakowie cieszyły się ogromnym zainteresowaniem uczestników.

Życie nie oszczędziło Maultsby'emu osobistych tragedii. Stracił obu synów w sile wieku: starszego Davida w wypadku szybowcowym, a młodszego, Maxie III, z powodu raka jelita grubego. Maultsby podzielił się tymi doświadczeniami z uczestnikami ostatnich warsztatów w Krakowie, opowiadając o tym, jak sobie z nimi radzil, stosując RTZ u samego siebie.

Podróż do Polski w 2013 r. i wykłady na warszawskiej SWPS i krakowskim UJ oraz trzydniowe warsztaty na UJ były ostatnimi publicznymi wystąpieniami profesora Maultsby'ego. Następnego roku nastąpiło gwałtowne pogorszenie jego stanu zdrowia związane z postępującym idiopatycznym włóknieniem płuc. Pod opieką kochającej żony Raili i hospicjum domowego, mimo złego rokowania, profesor Maultsby przeżył jeszcze ponad dwa lata we względnie dobrej jakości życia, praktycznie aż do końca ciesząc się wizytami rodziny i przyjaciół.
Niektóre wyjątkowe cechy Racjonalnej Terapii Zachowania:

- Inne terapie poznawczo-behawioralne wywodzą swoje pochodzenie $\mathrm{z}$ filozofii (szczególnie stoicyzmu), a Maultsby oparł RTZ na zasadach funkcjonowania ludzkiego mózgu, co było poparte wynikami badań Josepha LeDoux o uczeniu emocjonalnym jako uczeniu znaczenia bodźca, a nie reakcji na ten bodziec [9].

- RTZ jest najbardziej radykalną z terapii poznawczo-behawioralnych, ponieważ zakłada, jak mawiał Maultsby, że „poprzez nasze myśli, przekonania i postawy wytwarzamy, utrzymujemy i eliminujemy wszystkie nasze uczucia emocjonalne" - tak właśnie działa ludzki mózg [1]. Jest to zgodne ze zmodyfikowanym modelem Ellisa ABC(D) uczuć emocjonalnych [10].

- RTZ podkreśla samopomoc pacjenta (Rational Behavior Self-Counseling) i szkoli go, by sam stał się sobie terapeutą i dlatego w RTZ regularnie stosuje się pisemne zadania domowe i nagrywanie sesji dla pacjentów, by mogli jak najintensywniej stosować autoterapię między sesjami.

- RTZ uczy pacjentów, jak ocenić, co jest dla nich niezdrowym, a co zdrowym myśleniem; podkreśla przy tym, że to, co jest zdrowe dla jednej osoby (np. pacjenta), wcale nie musi być zdrowe dla innej (np. terapeuty), a nawet dla tej samej osoby $\mathrm{w}$ innym czasie.

- RTZ podkreśla, że u podłoża naszych nawyków leżą postawy, dobrze wyuczone niewerbalne formy myśli i przekonań.

- RTZ podkreśla, że praca może być niezwykle skuteczna w czasie kryzysu emocjonalnego; odkrywanie, skąd biorą się nasze uczucia, jest wtedy łatwiejsze, ponieważ nasze nawykowe, niewerbalne, niezdrowe postawy oraz przekonania są aktywnie myślane i względnie łatwe do zidentyfikowania. Właśnie dlatego w RTZ nie rozpoczynamy dysputy $\mathrm{z}$ niezdrowymi przekonaniami, dopóki wszystkie czynnie myślane przekonania nie zostaną zapisane, ponieważ przedwczesne dyskutowanie przekonań mogłoby zbyt szybko obniżyć poziom bólu emocjonalnego, a przez to zmniejszyć dostęp do pozostałych postaw i przekonań [11].

-W RTZ zgodnie z psychosomatyczną (racjonalną) teorią uczenia się [11, s. 82] uznaje się, że proces nabywania oraz zmiany nawyków emocjonalnych i poznawczych jest taki sam jak w przypadku nawyków fizycznych. Podczas zastępowania starych nawyków nowymi przechodzimy poprzez nieuniknioną fazę dysonansu poznawczo-emocjonalnego, kiedy nowe myśli, uczucia emocjonalne i zachowania są $\mathrm{w}$ konflikcie ze starymi - prowadzi to do wrażenia, 

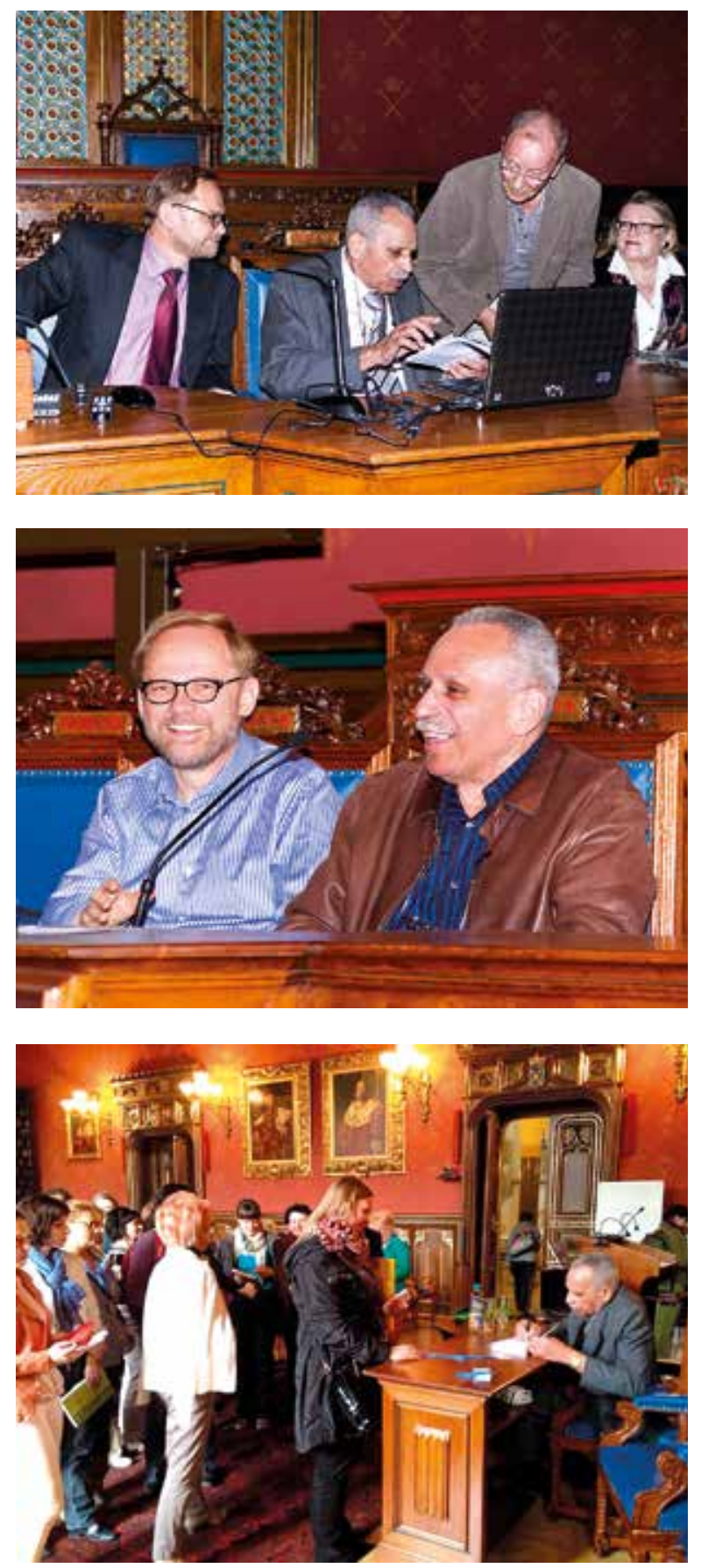

że nowe zachowanie "nie pasuje", wydaje się "nienaturalne", a nawet "niewłaściwe”, co często prowadzi do tego, że ćwiczenie nowych myśli i zachowań jest zarzucane. RTZ podkreśla, że należy uprzedzać pacjentów, iż uczucia związane $\mathrm{z}$ dysonansem poznawczo-emocjonalnym wystąpią, że są one znakiem właściwego procesu reedukacji emocjonalnej, dlatego należy je ignorować i ćwiczyć zdrowe myśli i zachowania tak długo, aż zaczną nam one "pasować" i staną się tak naturalne jak wszystkie inne nawyki.
-W RTZ uważa się, że wszelkie przyswajanie sobie nowych nawyków poznawczych, emocjonalnych i zachowania można przyspieszyć za pomocą racjonalnej wyobraźni emocjonalnej (RWE, jedna z technik pracy z wyobraźnią). Żeby zmienić jakiś nawyk, musimy ćwiczyć nowe zachowanie częściej niż stare, jednak codzienne życie nie dostarcza nam wystarczającej ilości okazji, żeby te nowe nawyki ćwiczyć (a jeżeli dostarcza, to często jesteśmy nieprzygotowani i znów reagujemy zgodnie ze starymi nawykami). Wyobraźnia pozwala nam ćwiczyć nowe myśli, uczucia i zachowania tyle razy, ile sobie życzymy, a następnie daje efekty w życiu rzeczywistym. Maultsby jako jeden z pionierów skutecznie zastosował ćwiczenia w wyobraźni ze sportowcami University of Wisconsin w Madison na podstawie grantu Correlation of Athletes' Estimates of Pre- and Post-Performance Tension with Urinary Catecholamine Excretion and Athletes' Performance (1969).

- RTZ podkreśla, zgodnie ze wskazówkami polskiego twórcy semantyki ogólnej [12], że nasze nawyki semantyczne mają niezwykły wpływ na emocje i nawyki te można względnie łatwo zmodyfikować, ćwicząc zdrową semantykę i unikając takich słów, jak "muszę”, "powinno być/powinienem”, „nie mogę" itp. [11].

- RTZ świetnie nadaje się do stosowania w sytuacji cierpienia związanego ze sferą duchową, religijną, głęboko filozoficzną czy egzystencjalną (Nondenominational, Cognitive-Behavioral Spiritual and/or Existential Counseling) [13].

Racjonalna Terapia Zachowania dalej rozwija się w Polsce - odbywają się szkolenia i warsztaty. Polscy master trainers są skupieni głównie przy Simontonowskim Instytucie Zdrowia; poza Aleksandrą Wirgą i mną są to: Agnieszka Hottowy, Aurelia Malec, Iwona Nawara, Maciej Skibiński oraz Ewa Wojtyna. Nowe wydanie $A B C$ twoich emocji, o podwójnej objętości i z ponad 200 ilustracjami, ma ukazać się w Polsce w przyszłym roku.

Na zakończenie osobista refleksja. „Doktor M.", bo tak na niego mówiliśmy w domu, miał na mnie wielki wpływ. Bardzo szczodrze dzielił się swoją wiedzą, był wspaniałym mentorem i serdecznym przyjacielem. Obcowanie z nim nie tylko zdefiniowało moją karierę zawodową, lecz także przekształciło mnie osobiście jako człowieka.

Już same podstawy RTZ, czyli ABCD emocji, i stwierdzenie, że my sami kształtujemy swoją rzeczywistość emocjonalną poprzez nasze myśli, przekonania i postawy oraz że możemy ją dowolnie zmieniać, jest niezwykle uwalniające, a równocześnie wiąże się $\mathrm{z}$ ostatecznym wzięciem odpowiedzialności za własne uczucia. Nie jest to nowe 
odkrycie - jest ono zgodne z zaleceniem Hipokratesa, ojca medycyny, który uważał, że „każdy człowiek powinien wiedzieć, że $\mathrm{z}$ umysłu, i tylko $\mathrm{z}$ umysłu, pochodzą nasze przyjemności, radość, śmiech, jak również żal, ból i łzy. Wszystkie te i inne uczucia pochodzą z umysłu i tylko z niego". Sto lat wcześniej Budda powiedzial, że poprzez swoje myśli kreujemy świat. Ten jeden wgląd - w źródło naszych uczuć - gdy jest rzeczywiście zinternalizowany, ma głęboki i transformujący wpływ na człowieka. A od niego dopiero zaczyna się cała Racjonalna Terapia Zachowania.

\section{Doktorze M., serdecznie dziękujemy. Będzie nam Ciebie brakowato.}

Mariusz Wirga

\section{Piśmiennictwo}

1. Maultsby Jr MC. Rational Behavior Therapy. Prentice Hall, Englewood Cliffs 1984.

2. Ellis A. Reason and Emotion in Psychotherapy, Revised and Updated. Carol Publishing Group, New York 1994.

3. Maultsby M. Rational emotive imagery. Rational Living 1971; 6: 24-27.

4. Simonton OC, Matthews-Simonton S, Creighton JL. Getting Well Again: a step-by-step, self-help guide to overcoming cancer for patients and their families. Tarcher, New York 1978.

5. Simonton OC, Henson RM, Hampton B. The Healing Journey. Bantam Books, New York 1992.

6. Wirga M. Zwyciężyć chorobę. Wyd. 2. Fundacja Alterna, Poznań 1991.

7. Wojtyna E. Irrational Suffering - An impact of cognitive behavioural therapy on the depression level and the perception of pain in cancer patients. W: L'Abate L (red.). Mental illnesses evaluation, treatments and implications. InTech, Rijeka 2012; 227-244.

8. Wojtyna E, Nawara I. Krótka grupowa racjonalna terapia zachowania a jakość życia chorych na nowotwory. Chowanna 2013; 1: 179-196.

9. LeDoux JE. In search of an emotional system in the brain: Leaping from fear to emotion and consciousness. W: The cognitive neurosciences. Gazzaniga MS (red.). MIT Press, Cambridge 1995; 1049-1061.

10. Wirga M, De Bernardi M. The ABCs of Cognition, Emotion, and Action. Archives of Psychiatry and Psychotherapy 2002; 4: 5-16.

11. Maultsby Jr MC. Racjonalna Terapia Zachowania: podręcznik terapii poznawczo-behawioralnej. Wirga M, Hottowy A, Wojtyna E (red. wyd. pol.). WDK Wulkan, Żnin 2013.

12. Korzybski A. Science and Sanity. Journal of Nervous and Mental Disease 1935; 82: 358-360.

13. Wirga M. Suffering: Its anatomy, physiology and mystique demystified from the Nondual Medicine Perspective. W: Binnebesel J, Formella Z, Krakowiak P, Domzal Z (red.). Experiencing a suffering. Tom 1. LAS - Libreria Ateneo Salesiano, Rome 2012; 121-147. 